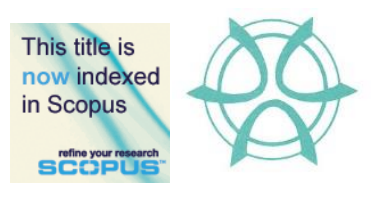

PLANNING MALAYSIA:

Journal of the Malaysian Institute of Planners

VOLUME 16 ISSUE 1 (2018), Page 372 - 380

\title{
ANCIENT MARITIME SYMBOLS IN MALAY TRADITIONAL BOAT IN THE EAST COAST, PENINSULAR MALAYSIA
}

\author{
Mohd Rohaizat Abdul Wahab ${ }^{1}$, Zuliskandar Ramli², Mohammad Anis Abdul \\ Samad $^{3}$, Nur Sarahah Mohd Supian ${ }^{4}$, Muhammad Nu'man Mohd Nasir' ${ }^{5}$ \& Siti \\ Salina Masdey ${ }^{6}$ \\ ${ }^{1}$ Institute for Mathematical Research \\ UNIVERSITI PUTRA MALAYSIA \\ ${ }^{2,4-6}$ Institute of the Malay World and Civilization \\ UNIVERSITI KEBANGSAAN MALAYSIA \\ ${ }^{3}$ Academy of Malay Studies \\ UNIVERSITI MALAYA, MALAYSIA
}

\begin{abstract}
The study on decorative arts in Malay culture has been widely discussed by domestic and foreign researchers. However, dedicated discussions on decorative arts on traditional Malay boats are still lacking. This article will discuss the discovery of ancient symbols, which was once used in Malay traditional boat arts, especially in the East Coast, Peninsular Malaysia. The objective of this study is to draw a similarity in the understanding of maritime society around the world about the use of ancient symbols on their boats. This study used a visual analysis approach based on the findings of images resembling ancient symbols that were found in boat decorations around the world. These symbols will be described by their meaning and relevance through the use of the iconographic method. The results of this study reveal the understanding and beliefs of maritime communities around the world that are almost identical in terms of their ancient symbols. One of the artistic uniqueness produced by the Malay community is the creation of ancient symbol in a distinctive way and it is also an iconic feature that is connected to the Malay sailor community in the East Coast.
\end{abstract}

Keyword: decorative arts, ornamental arts, traditional boat, ancient symbol, stylisation. 
PLANNING MALAYSIA

Journal of the Malaysia Institute of Planners (2018)

\section{INTRODUCTION}

The Malay art is formed from the mould and the manifestation of the local culture and the inclusion of various cultures. The art also gives way to the nature and identity of the Malays, which explains the value of a society, the way of life, and the influence of their traditional belief. The term 'Malay' refers to a community that is located in a vast territory, from Easter Island to Madagascar, and that they practice coastal culture. The Malay people who are proficient in the boat-making and sailing industries have travelled and scattered far across the globe. Furthermore, several researchers have discovered similar culture and language beyond these regions. The use of some terms - such as the Malayo-Polynesian and Austronesian by western researchers - refers to a common race of the Malays. Although the Malays have their own skills and capabilities in producing boats and water transportation equipment, the influence and use of external elements remain in the production of their boats and decorations.

This was the result of the spread of Malay sailors across outlying regions as well as the observation of the Malays on the boats that came to trade and docked at the harbours in the Malay World.

The production of decorative art on the traditional boats does not only exist in the Malay World, but in all maritime communities around the world, both in the East and in the West. The use of the figurehead on western boats is also a research focus dedicated on boat decorations in the west. The use of figurehead by western sailors is said to have begun around the 15th century. The figurehead was made of various shapes and engravings. In their beliefs, these figurehead decorations provide luck and control over their safety when they are in the middle of the sea. Wood carving that resembles human and animal forms is placed on the side of their boat. In the Malay community also, the use of ornaments on the boat has long been used that it garnered the attention of some western recorders who arrived in the Malay World. In Tome Pires's note, he had seen the boat used by the Malay community that was decorated with various dragon-shaped carvings. Manguin (2012) also stated that the decorations on the Malay boats around the 16th century were as follows;

"The state lancaras of Bintan in 1520, had their bows and stern beautifully decorated in gold in the way the princes of these places showed off the dignity of their service."

The Lancang boat painted by Manuel Godinho de Heredia around the 16th century also displayed the shape of a Malay boat that had carved ornaments on the bow and boat stern. However, there is no description of the small boat in the Malay world that had the aforementioned ornament, except for the illustration of the early Malay ship (that had decorations) as recorded by Smyth in 1902. 
Mohd Rohaizat, Zuliskandar, Mohammad Anis, Nur Sarahah, Muhammad Nu'man, \& Siti Salina

Ancient Maritime Symbols in Malay Traditional Boat in the East Coast, Peninsular Malaysia

\section{PROBLEM STATEMENT}

The boat decorations produced by the Malay community in the East Coast are ornamented artwork that were produced by a number of earlier generations and they were continued to be used on traditional boats. Decorations of the traditional boat in the East Coast are considered to be high art artefacts of the Malay art and it has its own distinctive features. The traditional Malay boats in the East Coast are furnished with decorative components, each of which has its own function. These components are decorated with certain motifs and has become a benchmark for the decoration of any boat's components. One of the components to be discussed in this research is an ancient symbol that appeared in the motif of a crane. This symbol was once discussed by James Hornell in some of his writings, such as the Survival of the Use of Oculi in Modern Boats and The Prow of the Ship: Sanctuary of the Tutelary Deity. However, the study of the use of this ancient symbol on traditional boats in the Malay World has yet to be carried out by researchers.

\section{THE USE OF MARITIME SYMBOLS BY SEAFARER AROUND THE WORLD}

When James Hornell served as Director of Fisheries in Madras, India circa 1908, he had studied all types of boats in India and in the surrounding areas. In his observations, he discovered that there were uniform symbols used on boats by the Hindus in India. The use of the oculus and sulur symbols had caught his attention, in which these symbols could be seen on traditional boats in India. His research on the symbol began in 1923, when he had discovered it on a boat in Portugal, along the coast of the Mediterranean, Madagascar, some of the African countries (such as Zanzibar), Swahili, and in some Central American countries. Agius (2007) also discovered the oculus and surul symbols on the Arabian boats along the Red Sea, the Persian Gulf, and the Arabian Sea. These symbols were also found on boats in China, Vietnam, Singapore, and other countries as shown in Table 1. The discoveries in these places prove that the use of this symbol is one that is universal, as used by various marine communities around the world. These symbols also do not have a uniformity and a specific form. The symbol also does not have a special place, unlike the Bahglah boat which has the oculus symbol placed on the boat's stern.

Culus is an eye-shaped symbol that is often placed on the bow of the boat. There are various forms of the eye found among them, as illustrated in Table 1. This symbol carries the meaning of vision, particularly when the boat sails in the middle of the sea. In the belief of the Chinese community, the oculus is important because each boat needs to have "eyes" in order to ease the sailing of the boats. The oculus serves as a direction indicator for a boat in the middle of the ocean and it also carries the spirit and protection from god (Hornell, 1923). Hornell also noted that the fishermen in Malta believed that by laying the oculus, their boat 
PLANNING MALAYSIA

Journal of the Malaysia Institute of Planners (2018)

had "life" and the spirit to navigate its direction in the ocean. Forde (1928) adds that this oculus is owned by all seafarers in the world, it protects the sailor who needs security during his voyage at sea.

The surul is a spiral or spiral symbol usually found in the bow of the boat. In the Malay society, surul or sulur is in a form of rolls and appears like a plant's shoot that is also widely used in carvings and other decorations. Haziyah, Zawiyah, Aminuddin and Aishah (2012) state that this surul or sulur takes on the image of makara. In the Hindu belief, the makara is an aquatic animal that becomes a vehicle of Vishnu when moving on the surface of the water. This makara image can also be found in front of the entrance to the candi (temple), which also serves as a guard and protector.

Table 1: Pictures of the oculus and sulur use worldwide

\begin{tabular}{|c|c|c|}
\hline Country & Symbol & Type of Boat \\
\hline India & & Jafna Dhoni \\
\hline Italy & & Guzzu \\
\hline Malta & & Dghajsa \\
\hline China & & Wenchow \\
\hline
\end{tabular}


Mohd Rohaizat, Zuliskandar, Mohammad Anis, Nur Sarahah, Muhammad Nu'man, \& Siti Salina Ancient Maritime Symbols in Malay Traditional Boat in the East Coast, Peninsular Malaysia

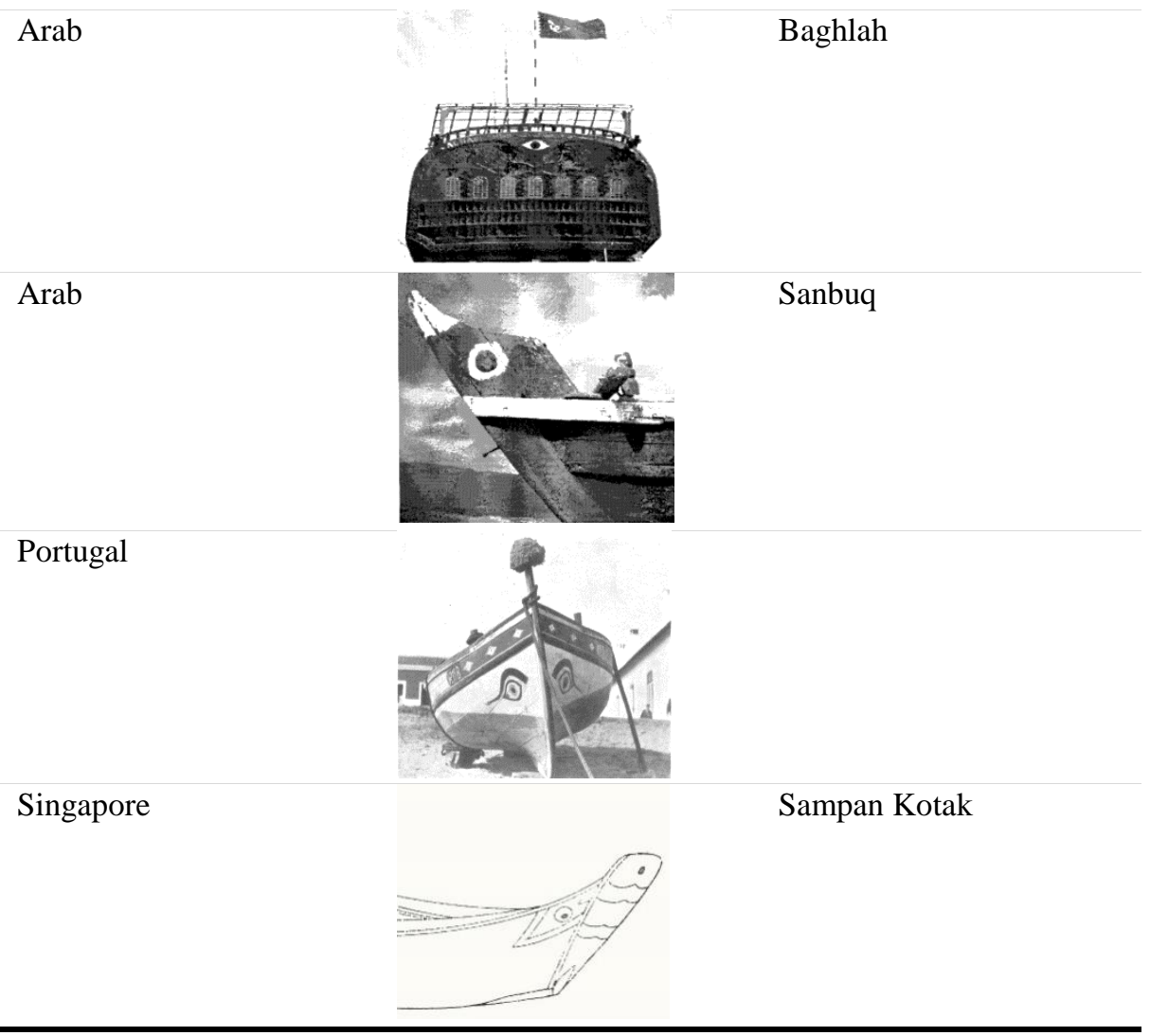

\section{THE USE OF OCULUS AND SULUR SYMBOLS IN THE MALAY COMMUNITY}

The use of a boat's decoration is an important part of the Malay community, especially in the East Coast. Differences in the name of the boat can also be distinguished by looking at the boat decoration, such as that of the Pinis Gobel boat and the Pinis Dogol boat. The Pinis Gobel boat has a spiral ornament on its bow (as illustrated), while the Pinis Dogol boat does not have any ornament on its bow. Similarly, the name "Dogol" used by Kelantan people is an indication of the lack of ornament on its bow. In the Kamus Dewan's fourth edition, 'dogol' means not having hair, horns, or bones on its head, which can also be interpreted that the boat has no ornament on its bow. 
PLANNING MALAYSIA

Journal of the Malaysia Institute of Planners (2018)

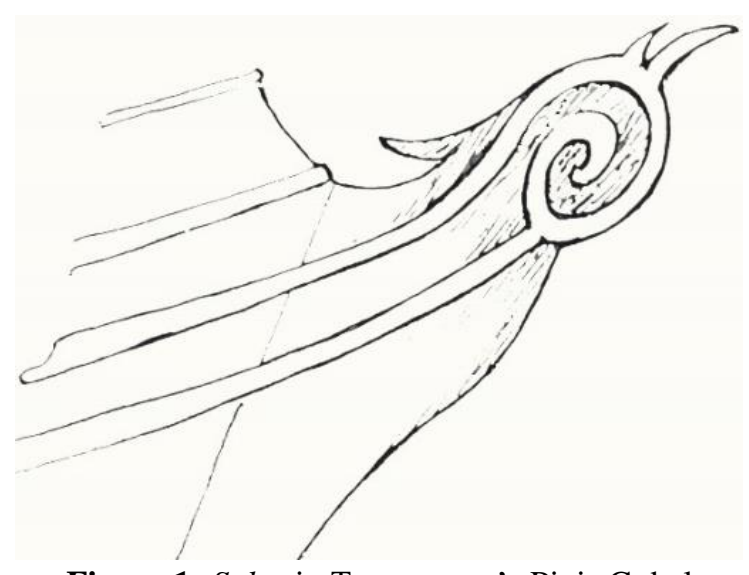

Figure 1: Sulur in Terengganu's Pinis Gobel

One of the interesting things in the boat on the East Coast is the use of decorative tools, such as head (kepala), crane (bangau), okok, caping, sangga tengah, sangga kemudi, cagak, and, koyang. However not all boats have this entire set of decorative appliances. Only the crane and okok are often used in all types of traditional Malay boats in the East Coast. Crane is a tool placed on the bow of the boat and serves as a prop on the mast and sails used by fishermen. The crane is made of hardwood, such as cengal (neobalanocarpus), meranti (shorea), jelutung (dyera costulata), and pulai (alstonia angustiloba). Most large cranes are over 1 meter long, 1 meter wide, and $5.5 \mathrm{~cm}$ thick; while for normal sized crane, it is about $40-60 \mathrm{~cm}$ high, $30-50 \mathrm{~cm}$ wide, and $4-5 \mathrm{~cm}$ thick. The crane is decorated with various carvings and paintings, furnishing the front and back of the crane. The front of the crane is the surface facing the sailors, while the back of the crane is the surface facing the ocean. The analysis of the findings of several storks has discovered that the front surface has a more beautiful and detailed carving than the back surface. According to Rosli (personal communication, $20^{\text {th }}$ February 2014), it is the practice and belief of the fishermen community in the East Coast that the sailors need to face the crane when the boat is sailing and they are also forbidden to step over and turn their backs facing the crane while the boat is sailing. According to Nik Abd. Rahman (2002), in the Malay community, the crane also has the function of being a protector and has the spirit that helps fishermen while working at sea. 
Mohd Rohaizat, Zuliskandar, Mohammad Anis, Nur Sarahah, Muhammad Nu'man, \& Siti Salina Ancient Maritime Symbols in Malay Traditional Boat in the East Coast, Peninsular Malaysia

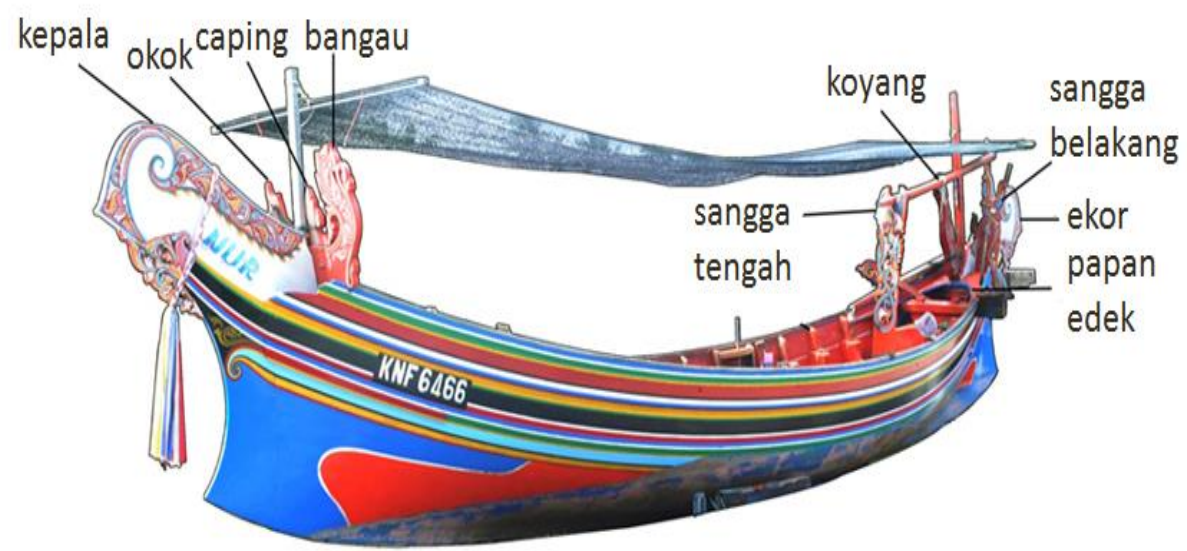

Figure 2: Boat's decoration on Western's produced boat

The use of the sulur can also be seen on the Western boat, where the sulur paintings are as clear as the elephant trunk on the bow and on the stern of the boat.

\section{VISUAL ANALYSIS ON CRANE SAMPLES}

In the visual analysis of the motives used in the 137 crane samples analysed, it is found that the motifs often found in crane samples are sulur motifs, while certain characters have the image of an eye.
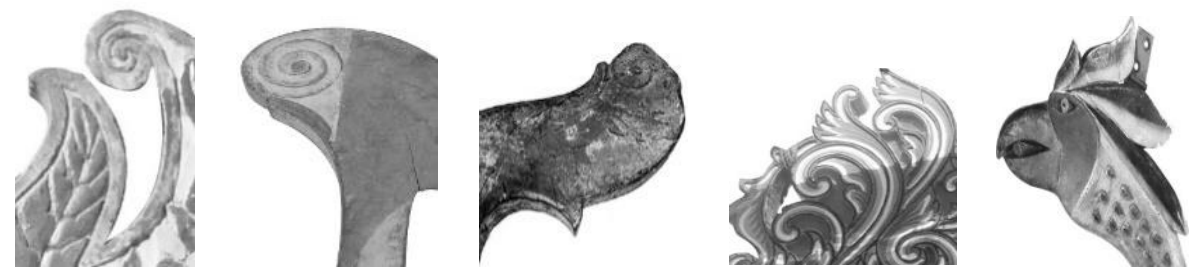

Figure 3: Findings of the Sulur image on the crane decoration
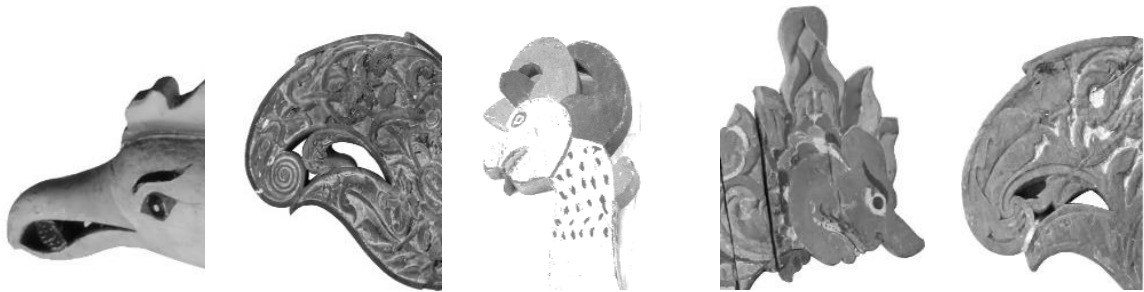

Figure 4: Findings of the Oculus image on the crane decoration 
PLANNING MALAYSIA

Journal of the Malaysia Institute of Planners (2018)

The images that have been found are stylised according to their suitability and used different approaches to distinguish them from the boats found in other countries. The interpretation and understanding of marine communities around the world on this symbol are the same, but the style of the process of the Malay society is quite different from those of the other societies.

\section{DISCUSSION}

The symbols and designs produced are the stylisation of the symbols used by ancient seafarers throughout the world. This symbol has become a belief and it is used on sailors' boats, especially in India. The use of the Oculus and surul symbols are used in the traditional Malay ornamental art of the East Coast, Peninsular Malaysia, but with different processes and styles. The spread of this symbol may occur from the relationship and interaction between the Malay community and the outside world, especially the people from India. However, with the creative leverage and intelligence of the Malay community, these symbols are fashioned in a more unique style and would showcase the identity of the Malays.

The understanding of the Malay community on some matters in marine affairs is also similar to other societies. For example, the Malays are of the belief that there are creatures or external forces that are in the middle of the ocean - in which they would hold a ceremony or ritual for ship launching, or a beach puja ceremony. The old understanding and belief was influenced by the ones brought in by foreign traders.

\section{CONCLUSION}

The craftiness and authenticity of producing art is one of the characteristics for the Malay artisans, but the production is based on a relationship of belief and understanding that has long existed in its environment. The Malays - who master the craftsmanship and handicrafts - could produce different artistry that are distinctive from other societies. Although the understanding of the symbols may be the same, but with the creative superiority and intelligence of the Malay community, it was produced in a distinctive style. This art also has connections to the teachings of Islam that prevents non-religious beliefs yet retain some of its traditional and pre-Islamic influence. The art produced, such as the crane, proved the Malays' ingenious method in laying old symbols and beliefs in oceanography. 
Mohd Rohaizat, Zuliskandar, Mohammad Anis, Nur Sarahah, Muhammad Nu'man, \& Siti Salina

Ancient Maritime Symbols in Malay Traditional Boat in the East Coast, Peninsular Malaysia

\section{ACKNOWLEDGEMENT}

This research was carried out with the assistance of the research grant DCP-2017008/1 and TD-2014-005. Therefore, we would like to express our gratitude to the Ministry of Higher Education, and The National University of Malaysia (UKM) for the research grants awarded.

\section{REFERENCES}

Agius, D. A. (2007). Decorative motifs on Arabian boats: Meaning and identity. In J. Starkey, P. Starkey, \& T. Wilkinson (Eds.). Natural resources and cultural connections of the Red Sea (pp. 101-110). Oxford: Arcaheopress.

Forde, C. D. (1928). Ancient mariners: The story of ships and sea routes. New York: William Morrow \& Company.

Haziyah, H., Zawiyah, B., Aminuddin, H., \& Aishah, H. M. (2012). The philosophy in the creation of traditional Malay carving motifs in Peninsula Malaysia. Malaysia Journal of Society and Space, 8(7), 88-95.

Hornell, J. (1923). Survival of the use of oculi in modern boats. Journal of the Royal Anthropological Institute of Great Britain and Ireland, 53, 289-321.

Manguin, P. (2012). Lancaran, Ghurab and Ghali: Mediterranean impact on war vessels in early modern Southeast Asia. In G. Wade \& L. Tana (Eds.), anthony reid and the study of the Southeast Asian past (pp. 146-182). Singapore: ISEAS-Yusof Ishak Institute.

Nik Abd. Rahman, N. H. S. (2002). Sejarah Kelantan sebelum Long Yunus - Satu gambaran umum. In Nik Hassan Shuhaimi Nik Abd. Rahman (Ed.), Kelantan zaman awal: Kajian arkeologi dan sejarah (pp.1-14). Kelantan: Perbadanan Muzium Negeri Kelantan.

Smyth, H. W. (1902). Boats and boat building in the Malay Peninsula. Journal of the Society of Arts, 570-588. 